\title{
Evaluation of Two Control Strategies for Induction Machine
}

\author{
Hamid Chaikhy \\ Hassan II University-ENSEM \\ BP 8118, Oasis, Casablanca, \\ Morocco.
}

\author{
Mohamed Khafallah \\ Hassan II University-ENSEM \\ BP 8118, Oasis, Casablanca, \\ Morocco.
}

\author{
Abdallah Saad \\ Hassan II University-ENSEM \\ BP 8118, Oasis, Casablanca, \\ Morocco.
}

\begin{abstract}
This paper presents a contribution for detailed comparison between two control strategies for Induction Machine (IM) drives: Direct Field-Oriented control (DFOC) and Direct Torque Control (DTC). The performances of those two control schemes are evaluated and compared by simulation in terms of torque and current ripples, transient response and sensitivity to machine parameters.
\end{abstract}

\section{Keywords}

DFOC, DTC, Steady-state performance, transient performance,

Parameter sensitivity.

\section{NOMENCLATURE}

$\begin{array}{ll}\mathrm{i}_{\mathrm{qs}}, \mathrm{i}_{\mathrm{ds}} & : \text { d and q components stator current, }(\mathrm{A}) \\ \mathrm{i}_{\mathrm{qr}}, \mathrm{i}_{\mathrm{dr}} & : \text { d and q components rotor current, }(\mathrm{A}) \\ \mathrm{V}_{\mathrm{s}} & : \text { Stator voltage } \\ \mathrm{V}_{\mathrm{ds}}, \mathrm{V}_{\mathrm{qs}} & : \text { d and q components stator voltage, }(\mathrm{V}) \\ \mathrm{V}_{\mathrm{dr}}, \mathrm{V}_{\mathrm{qr}} & : \text { d and q components rotor voltage, }(\mathrm{V}) \\ \Psi_{\mathrm{s}}, \Psi_{\mathrm{r}} & : \text { Stator and rotor flux, }(\mathrm{Wb}) \\ \Psi_{\mathrm{ds}}, \Psi_{\mathrm{qs}} & : \text { d and q components stator flux, }(\mathrm{Wb}) \\ \Psi_{\mathrm{dr}}, \Psi_{\mathrm{qr}} & : \text { d and q components rotor flux, }(\mathrm{Wb}) \\ \mathrm{R}_{\mathrm{s}}, \mathrm{R}_{\mathrm{r}} & : \text { Stator and rotor resistance, }(\Omega) \\ \mathrm{L}_{\mathrm{s}}, \mathrm{L}_{\mathrm{r}} & : \text { Stator and rotor Inductance, }(\mathrm{H}) \\ \mathrm{M} & : \text { Mutual Inductance } \\ \mathrm{T}_{\mathrm{r}} & : \text { Rotor time constant } \\ \mathrm{T}_{\mathrm{s}} & : \text { Stator time constant } \\ \mathrm{p} & : \text { Pole pairs number } \\ \sigma & : \text { Leakage factor } \\ \omega_{\mathrm{r}} & : \text { Slip frequency, }(\text { rad.s-1) } \\ \mathrm{T} & : \text { Electromagnetic torque, }(\mathrm{Nm}) \\ \mathrm{T}_{1} & : \text { Load torque, }(\text { Nm) } \\ \mathrm{J} & : \text { Inertia moment } \\ \mathrm{f} & : \text { Coefficient of viscous friction }\end{array}$

\section{INTRODUCTION}

Induction machines (IM) have been widely used in industry because of their advantages: simple construction, ruggedness, reliability, low cost, and a minimum of maintenance. However, due to their highly-coupled nonlinear structure, a highperformance control of IM is a challenging problem. Several control strategies have been used for induction machine drives as: Field Oriented Control (FOC) [1], Direct Torque Control (DTC) [2], and direct self control (DSC) [3].

In 1970, the principle of field oriented control (FOC) of IM was proposed. The (FOC) appeared to have similar performance to the DC machine over a wide range of speed and load conditions, but the performance of a FOC implementation depends critically on a very accurate coordinate transformations and flux angle estimation, which are complex and depending on the variation of machine parameters. For this reason, many studies have been performed into finding various solutions that enable the IM control to have a quick torque response, and to reduce the complexity of FOC.

Since direct torque control (DTC) was introduced in the mid-1980s, it has been widely used for IM drives. Besides its simplicity, DTC is able to produce fast torque and flux control and, if the torque and flux can be estimated correctly, DTC become robust. However, it is well known that DTC presents some disadvantages, such as the variable switching frequency behavior of the inverter, the notable torque, flux and current ripples, also DTC scheme greatly affected by the change of the stator resistance especially when the motor runs at low speeds.

Recently, much effort has been made to improve the performance of DTC, especially by reducing the ripples, and by fixing the inverter switching frequency [8]-[10].

Several papers have been published on FOC and DTC in the last 30 years, but only few of them was aimed to emphasize differences, advantages and disadvantages [4]-[7].

The aim of this paper is to compare the performances of both DFOC and DTC when applied to IM drives and point out the strengths and weaknesses that can help to make a choice between them for a particular application. Before analyzing the two methods it is very important to establish the conditions to have a fair comparison between them.

The paper starts by presenting the IM model and the operating principles of DFOC and DTC. This will be followed by an explanation of the comparative analysis and simulation tests performed, the main characteristics, advantages and disadvantages of both methods will be showed and discussed in the results of the simulation tests. Finally, this work will give a study of sensitivity of the two control scheme to machine parameters and presents a summary of the comparison between FOC and DTC not only regarding the performance but also considering the control structure and requirements of both systems. 


\section{INDUCTION MACHINE DYNAMIC MODEL}

In the stationary reference frame fixed on stator, the mathematical equations of IM can be written as follows:

- Stator and rotor voltage equations:

$$
\begin{aligned}
& V s=R_{s} i_{s}+\frac{d \Psi_{s}}{d t} \\
& 0=R_{s} i_{r}+\frac{d \Psi_{r}}{d t}-j \omega \Psi_{r}
\end{aligned}
$$

- Stator and rotor flux equations:

$$
\begin{aligned}
& \psi_{\mathrm{s}}=\mathrm{L}_{\mathrm{s}} \mathrm{i}_{\mathrm{s}}+\mathrm{Mi}_{\mathrm{r}} \\
& \psi_{\mathrm{r}}=\mathrm{L}_{\mathrm{r}} \mathrm{i}_{\mathrm{r}}+\mathrm{Mi}_{\mathrm{s}}
\end{aligned}
$$

- Mechanical dynamic equation:

$$
\mathrm{J} \frac{\mathrm{d} \Omega}{\mathrm{dt}}=\mathrm{T}-\mathrm{f} \Omega-\mathrm{T}_{\mathrm{l}}
$$

- Electromagnetic torque:

$$
T=p \frac{M}{L_{r}}\left(\psi_{d r} i_{q s}-\psi_{q r} i_{d s}\right)
$$

\section{PRINCIPLE OF FOC}

The field oriented control was introduced by Blaschke in 1972. Since then, it has been the widely used control for IM drives. This technique allows independent control of the torque and flux of the dynamic machine. This is done by direct or indirect flux orientation. In the direct field oriented control (DFOC) strategy, both the instantaneous magnitude and position of the rotor flux are supposed to be directly measured or estimated.

In Fig.1, the block diagram of the DFOC control technique for IM is shows:

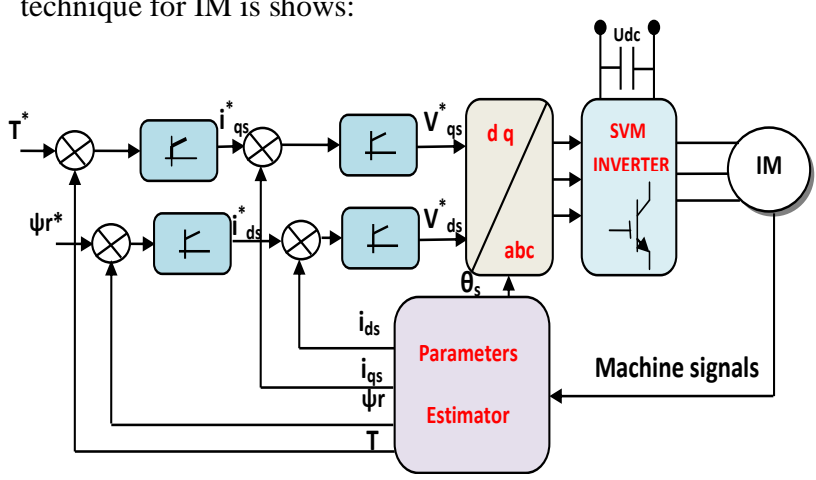

Fig.1: block diagram of the DFOC control technique for IM
Assuming a rotor flux reference frame, and developing the previous equations with respect to the axis and axis components.

The condition of flux rotor orientation is $\Psi_{q r}=0$ Consequently, the FOC equations become:

$$
\begin{gathered}
\psi_{r}=\psi_{d r} \\
\mathrm{~T}=\mathrm{p} \frac{\mathrm{M}}{\mathrm{L}_{\mathrm{r}}} \psi_{r} \mathrm{i}_{\mathrm{qs}} \\
\psi_{r}=\frac{\mathrm{M}}{1+\mathrm{T}_{\mathrm{r}} \mathrm{s}} \mathrm{i}_{\mathrm{ds}}
\end{gathered}
$$

$$
\mathrm{V}_{\mathrm{ds}}^{*}=\sigma \mathrm{L}_{\mathrm{s}} \frac{\mathrm{di} \mathrm{ds}_{\mathrm{dt}}}{\mathrm{dt}}+\mathrm{R}_{\mathrm{s}} \mathrm{i}_{\mathrm{ds}}-\sigma \mathrm{L}_{\mathrm{s}} \omega_{\mathrm{s}} \mathrm{i}_{\mathrm{qs}}+\frac{\mathrm{M}}{\mathrm{L}_{\mathrm{r}}} \frac{\mathrm{d} \Psi_{\mathrm{r}}}{\mathrm{dt}}
$$

$$
\mathrm{V}_{\mathrm{qs}}^{*}=\sigma \mathrm{L}_{\mathrm{s}} \frac{\mathrm{di}_{\mathrm{qs}}}{\mathrm{dt}}+\mathrm{R}_{\mathrm{s}} \mathrm{i}_{\mathrm{qs}}-\sigma \mathrm{L}_{\mathrm{s}} \omega_{\mathrm{s}} \mathrm{i}_{\mathrm{ds}}+\frac{\mathrm{M}}{\mathrm{L}_{\mathrm{r}}} \omega_{\mathrm{s}} \psi_{\mathrm{r}}
$$

Where:

$$
\mathrm{T}_{\mathrm{r}}=\frac{\mathrm{L}_{\mathrm{r}}}{\mathrm{R}_{\mathrm{r}}} \quad \text { And } \sigma=1-\frac{\mathrm{M}^{2}}{\mathrm{~L}_{\mathrm{r}} \mathrm{L}_{\mathrm{s}}}
$$

\section{PRINCIPLE OF DTC}

Since M. Depenbrock and I. Takahashi proposed direct torque control (DTC) for IM in the middle of 1980's, more than decade has passed. It is getting more and more popular nowadays. The basic idea of DTC for IM is to control the voltage space vectors properly, which is based on the relationship between the slip frequency and torque.

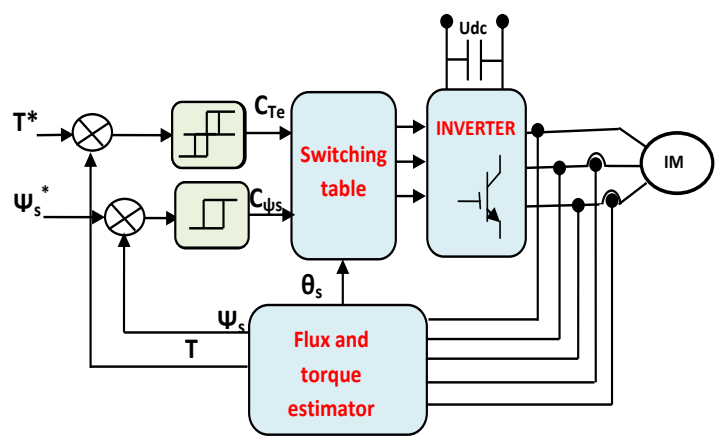

Fig.2: block diagram of the DTC control technique for IM

by using a $\alpha-\beta$ stationary stator reference frame, the stator flux linkage $\Psi_{S}$ and electromagnetic torque $\mathrm{T}$ are calculated by using: 


$$
\psi_{\mathrm{s}}=\sqrt{\left(\psi_{\alpha \mathrm{s}}\right)^{2}+\left(\psi_{\beta \mathrm{s}}\right)^{2}}
$$

Where:

$$
\begin{array}{r}
\Psi_{\alpha s}=\int_{0}^{t}\left(V_{\alpha s}-R_{s} i_{\alpha s}\right) d t \\
\psi_{\beta s}=\int_{0}^{t}\left(V_{\beta s}-R_{s} i_{\beta s}\right) d t
\end{array}
$$

The angle $\theta_{\mathrm{s}}$ is equal to:

$$
\begin{gathered}
\theta_{s}=\operatorname{artg}\left(\frac{\Psi_{\beta s}}{\Psi_{\alpha s}}\right) \\
\mathrm{T}=\mathrm{p}\left[\psi_{\alpha s} \mathrm{i}_{\beta s}-\psi_{\beta s} i_{\alpha s}\right]
\end{gathered}
$$

The error between the estimated torque $\mathrm{T}$ and the reference torque $\mathrm{T}^{*}$ is the input of a three level hysteresis comparator, whereas the error between the estimated stator flux magnitude $\psi_{\mathrm{s}}$ and the reference stator flux magnitude $\psi_{S}^{*}$ is the input of a two level hysteresis comparator.

The selection of the appropriate voltage vector is based on the switching table given in Table 1 . The input quantities are the flux sector and the outputs of the two hysteresis comparators.

Assuming the stator flux vector lying in sector 1 of the d-q plane, the voltage vectors used by DTC technique are shown

\begin{tabular}{|c|c|c|c|c|c|c|c|}
\hline \multirow{2}{*}{\multicolumn{2}{|c|}{ Outputs of hysteresis comparators }} & \multicolumn{6}{|c|}{ Sector } \\
\hline & & $\mathbf{1}$ & 2 & 3 & 4 & 5 & 6 \\
\hline \multirow{3}{*}{$C_{\psi s}=-1$} & $C_{T}=-1$ & $\overline{\mathrm{V}}_{2}$ & $\overline{\mathrm{V}}_{3}$ & $\overline{\mathrm{V}}_{4}$ & $\overline{\mathrm{V}}_{5}$ & $\overline{\mathrm{V}}_{6}$ & $\overline{\mathrm{V}}_{1}$ \\
\hline & $C_{T}=0$ & $\overline{\mathrm{V}}_{7}$ & $\overline{\mathrm{V}}_{0}$ & $\overline{\mathrm{V}}_{7}$ & $\overline{\mathrm{V}}_{0}$ & $\overline{\mathrm{V}}_{7}$ & $\overline{\mathrm{V}}_{0}$ \\
\hline & $C_{T}=+1$ & $\overline{\mathrm{V}}_{6}$ & $\overline{\mathrm{V}}_{1}$ & $\overline{\mathrm{V}}_{2}$ & $\overline{\mathrm{V}}_{3}$ & $\overline{\mathrm{V}}_{4}$ & $\overline{\mathrm{V}}_{5}$ \\
\hline \multirow{3}{*}{$C_{\psi s}=+\mathbf{1}$} & $C_{T}=-1$ & $\overline{\mathrm{V}}_{3}$ & $\overline{\mathrm{V}}_{4}$ & $\overline{\mathrm{V}}_{5}$ & $\overline{\mathrm{V}}_{6}$ & $\overline{\mathrm{V}}_{1}$ & $\overline{\mathrm{V}}_{2}$ \\
\hline & $C_{T}=0$ & $\overline{\mathrm{V}}_{0}$ & $\overline{\mathrm{V}}_{7}$ & $\overline{\mathrm{V}}_{0}$ & $\overline{\mathrm{V}}_{7}$ & $\overline{\mathrm{V}}_{0}$ & $\overline{\mathrm{V}}_{7}$ \\
\hline & $C_{T}=+1$ & $\overline{\mathrm{V}}_{5}$ & $\overline{\mathrm{V}}_{6}$ & $\overline{\mathrm{V}}_{1}$ & $\overline{\mathrm{V}}_{2}$ & $\overline{\mathrm{V}}_{3}$ & $\overline{\mathrm{V}}_{4}$ \\
\hline
\end{tabular}
in Fig.3.

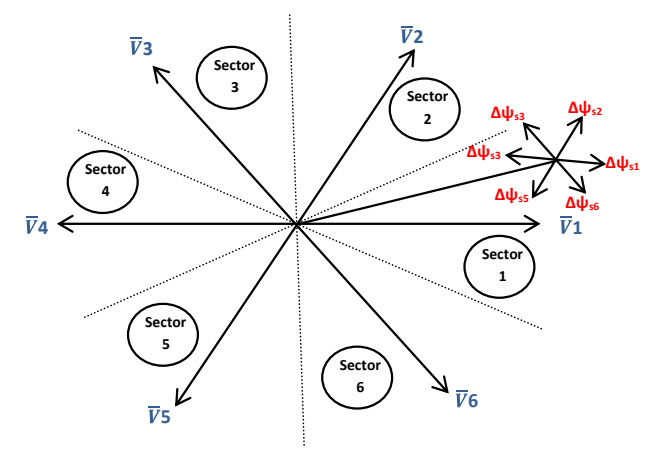

Fig.3. Voltage vectors utilized in basic scheme when stator flux is in sector 1.
Table 1. Basic switching

\section{COMPARISON BETWEEN FOC AND DTC}

This section is aimed to give a contribution for a fair comparison between the two control techniques. The quantities used to evaluate the performance of DFOC and DTC, in steady state and transient conditions, are:

- Current and torque ripple values in steady-state operating conditions.

- Time response to a step variation of the torque command, at different rotor speeds.

For a fair comparison of the two schemes the following criteria have been adopted, the same average switching frequency of the inverter.

For that, the amplitude of the hysteresis bands have been adjusted in order to achieve a mean inverter switching frequency practically equal to that of DFOC scheme.

\subsection{Steady-state performance}

The steady-state performance of DFOC and DTC schemes has been compared evaluating the three-phase rms current ripple in different operating conditions. For this purpose the threephase rms current ripple, defined by

$$
I_{\text {rip }-r m s}=\sqrt{\frac{1}{T} \int_{0}^{T}\left(i_{\text {ripA }}^{2}+i_{\text {rip } B}^{2}+i_{\text {rip } C}^{2}\right) d t}
$$

The results obtained using DFOC and DTC schemes are summarized in Tables 2 and 3, respectively. The considered operating conditions are related to rotor speed values of $100 \%$, $50 \%$, and $10 \%$ of the rated value, and torque values of $100 \%$, $50 \%$, and $0 \%$ of the rated value. 
Table 2. Three-phase rms current ripple (DFOC)

\begin{tabular}{|c|c|c|c|}
\hline & $\mathbf{1 4 4 0} \mathbf{~ r p m}$ & $\mathbf{7 4 0} \mathbf{~ r p m}$ & $\mathbf{1 0 0} \mathbf{~ p m}$ \\
\hline $\mathbf{1 0} \mathbf{~ N m}$ & $0.31 \mathrm{~A}$ & $0.54 \mathrm{~A}$ & $0.38 \mathrm{~A}$ \\
\hline $\mathbf{5} \mathbf{~ N m}$ & $0.32 \mathrm{~A}$ & $0.54 \mathrm{~A}$ & $0.37 \mathrm{~A}$ \\
\hline $\mathbf{0 ~ N m}$ & $0.33 \mathrm{~A}$ & $0.53 \mathrm{~A}$ & $0.35 \mathrm{~A}$ \\
\hline
\end{tabular}

Table 3. Three-phase rms current ripple (DTC)

\begin{tabular}{|c|c|c|c|}
\hline & 1440 rpm & $\mathbf{7 4 0} \mathbf{~ r p m}$ & $\mathbf{1 0 0} \mathbf{~ r p m}$ \\
\hline $\mathbf{1 0} \mathbf{~ N m}$ & $0.52 \mathrm{~A}$ & $0.85 \mathrm{~A}$ & $0.80 \mathrm{~A}$ \\
\hline $\mathbf{5 ~ N m}$ & $0.53 \mathrm{~A}$ & $0.84 \mathrm{~A}$ & $0.79 \mathrm{~A}$ \\
\hline $\mathbf{0 ~ N m}$ & $0.54 \mathrm{~A}$ & $0.84 \mathrm{~A}$ & $0.76 \mathrm{~A}$ \\
\hline
\end{tabular}

As it is possible to see, in all the operating conditions the behavior of DFOC scheme is characterized by lower values of the three-phase rms current ripple according to DTC scheme.

The torque, the stator current waveform and the stator current harmonic spectrum obtained with DFOC scheme are shown in Fig.4 (a)-(c), respectively. Fig.5 (a)-(c) shows the same quantities obtained when using DTC scheme. The rotor speed is $1440 \mathrm{rpm}$ and the reference torque is $10 \mathrm{Nm}$ (rated torque).
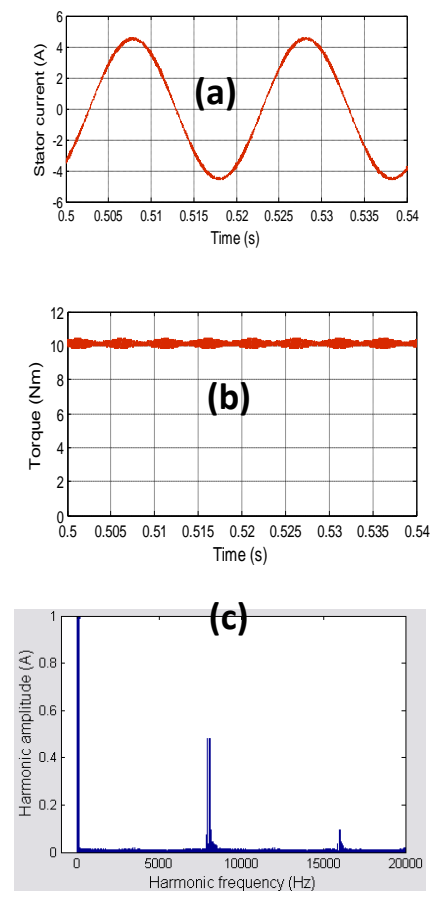

Fig.4.(a) Stator current. (b) Torque. (c) Stator current harmonic spectrum in DFOC

\section{2 transient performance}

The transient performance of the two schemes has been compared analyzing the response to a step variation of the torque command from $0 \mathrm{Nm}$ to $10 \mathrm{Nm}$ (rated torque), at different rotor speeds.

Fig.6 and Fig.7 show the results obtained for a step variation of the torque command from 0 to $10 \mathrm{Nm}$, at different rotor speeds (1440 rpm,720 rpm and $100 \mathrm{rpm}$ ),respectively for DFOC and DTC. These results show that using the DTC scheme, a better torque response can be achieved in terms of settling time and maximum overshoot. The different dynamic behavior is due to presence of PI regulators in DFOC scheme, which delay the torque response. The settling times for the two cases are summarized in Table 4.

Table 4. Settling time of the torque response

\begin{tabular}{|c|c|c|}
\hline & FOC & DTC \\
\hline $\mathbf{1 4 4 0} \mathbf{~ r p m}$ & $7.5 \mathrm{~ms}$ & $2.1 \mathrm{~ms}$ \\
\hline $\mathbf{7 4 0} \mathbf{~ r p m}$ & $5 \mathrm{~ms}$ & $1.2 \mathrm{~ms}$ \\
\hline $\mathbf{1 0 0} \mathbf{~ r p m}$ & $4,5 \mathrm{~ms}$ & $1 \mathrm{~ms}$ \\
\hline
\end{tabular}
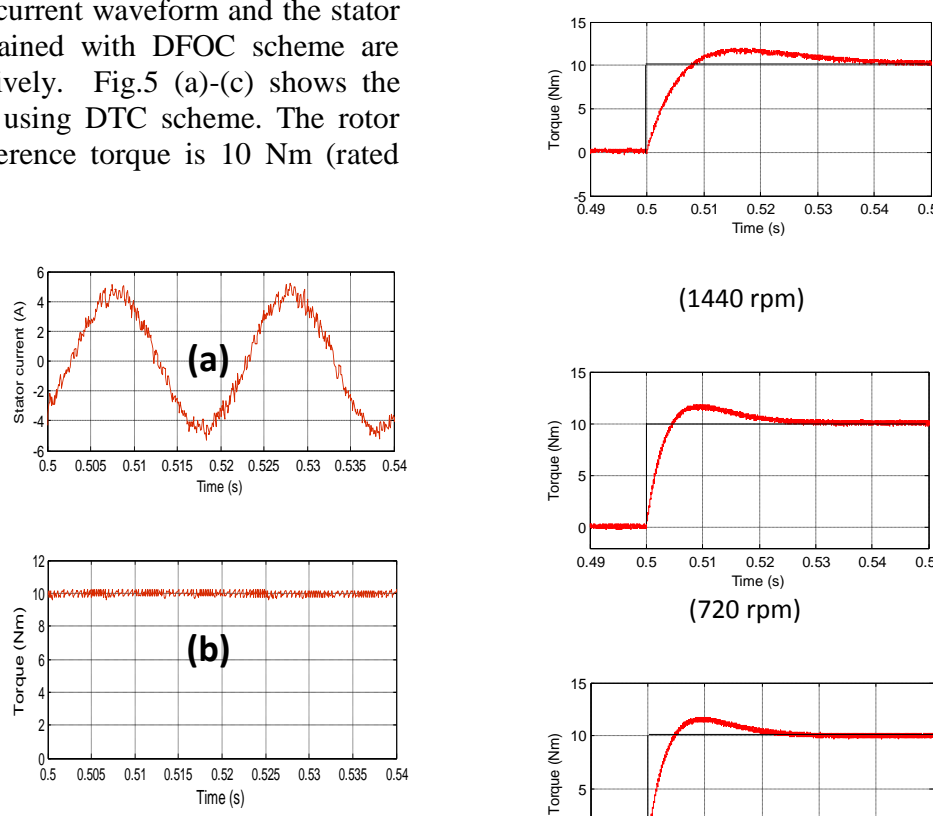

(1440 rpm)

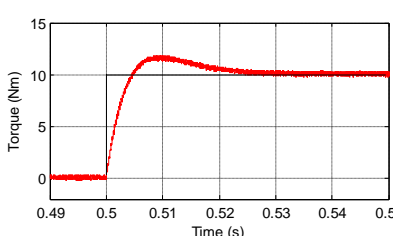

(720 rpm)

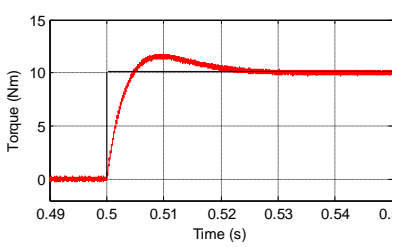

(100 rpm)

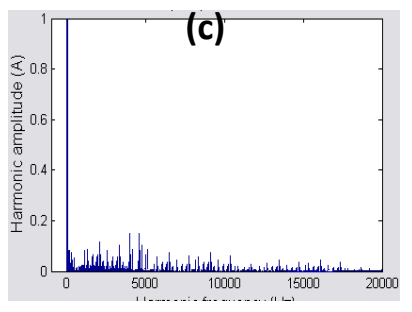

Fig.5.(a) Stator current. (b) Torque. (c) Stator current harmonic spectrum in DTC
Fig.6. Evolution of torque response for different speeds in DFOC scheme

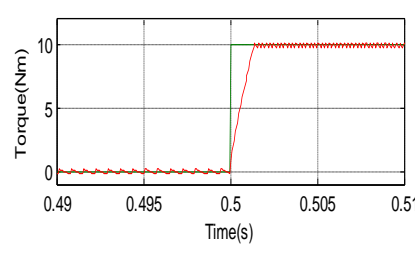

(1440 rpm)

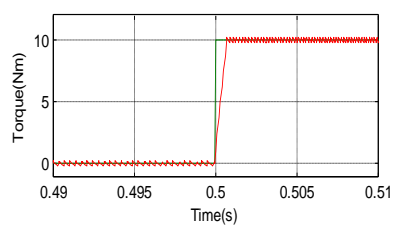

(720 rpm)

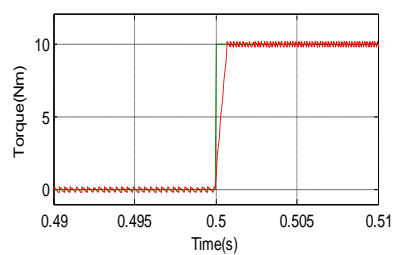

(100 rpm)

(100rpm)

Fig.7. Evolution of torque response for different speeds in DTC scheme 


\section{DTC BEHAVIOR AT LOW SPEED}

It is known that the basic DTC scheme is affected by undesired flux weakening phenomena at low speed. In these operating conditions the control system selects many times zero voltage vectors, determining a reduction of the flux level owing to the effects of the stator resistance voltage drop. Fig. 8 shows the stator flux variations obtained by numerical simulations at a rotor speed of $10 \mathrm{rpm}$, and with a torque of $5 \mathrm{Nm}$.

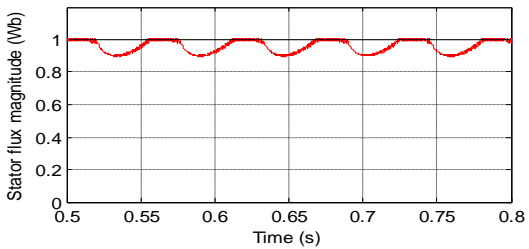

Fig.8. Stator flux variations at a rotor speed of $10 \mathrm{rpm}$

Table 5. Summary of the comparison between DFOC and DTC

\begin{tabular}{|c|c|c|}
\hline & DFOC & DTC \\
\hline $\begin{array}{c}\text { Dynamic response for } \\
\text { torque }\end{array}$ & Slower & Quicker \\
\hline $\begin{array}{c}\text { Steady-state behavior } \\
\text { for torque, stator and } \\
\text { currents }\end{array}$ & $\begin{array}{r}\text { Low ripple } \\
\text { and distortion }\end{array}$ & $\begin{array}{l}\text { High ripple and } \\
\text { distortion }\end{array}$ \\
\hline $\begin{array}{c}\text { Behavior at Low } \\
\text { Speed }\end{array}$ & good & Not good \\
\hline Parameter sensitivity & Sensitive & $\begin{array}{c}\text { Not big sensitive } \\
\text { unsteady behavior if } \\
\text { stator resistance over- } \\
\text { estimation }\end{array}$ \\
\hline $\begin{array}{c}\text { Requirement of rotor } \\
\text { position }\end{array}$ & Yes & No \\
\hline Current control & Yes & No \\
\hline $\begin{array}{c}\text { Coordinate } \\
\text { transformation }\end{array}$ & Yes & No \\
\hline Switching frequency & Constant & $\begin{array}{c}\text { Variable, depending on the } \\
\text { operating point and } \\
\text { during transients }\end{array}$ \\
\hline Audible noise & $\begin{array}{l}\text { Low noise at a } \\
\text { fixed } \\
\text { frequency }\end{array}$ & $\begin{array}{c}\text { Spread spectrum, high } \\
\text { noise especially at low } \\
\text { speed }\end{array}$ \\
\hline Control tuning & PI gains & Hysteresis bands \\
\hline $\begin{array}{l}\text { Complexity and } \\
\text { processing } \\
\text { requirements }\end{array}$ & Higher & Lower \\
\hline
\end{tabular}

Finally, Table.5 presents a summary of the comparison between DTC and DFOC not only regarding the performance but also considering the control structure and requirements of both systems.

\section{CONCLUSION}

This paper has presented a comparison between two vector control methods for IM drives: FOC and DTC. The description of both control schemes and their principle of operation has been presented. The criterions for a fair comparison between FOC and DTC have been established and the results of simulation tests have been presented to show the performance of both methods in various conditions. Summarizing, it can be said that both methods provide a high performance response with quicker torque dynamics and less sensitivity to machine parameters in the case of DTC and better steady-state behavior for FOC. Depending on the requirements of a particular application one method can be more convenient than the other.

Table 6. Parameters of induction machine

\begin{tabular}{|c|c|}
\hline Stator resistance & $\mathrm{Rs}=5,63 \Omega$ \\
\hline Rotor resistance & $\mathrm{Rr}=2,62 \Omega$ \\
\hline Rotor/ Stator inductances & $\mathrm{Ls}=\mathrm{Lr}=0,382 \mathrm{H}$ \\
\hline Magnetizing Inductance & $\mathrm{M}=0,364 \mathrm{H}$ \\
\hline Moment of inertia & $\mathrm{J}=0,010 \mathrm{Kg} . \mathrm{m} 2$ \\
\hline Viscous inertia & $\mathrm{F}=0,015 \mathrm{~N} . \mathrm{m} . \mathrm{s} \cdot \mathrm{rad}-1$ \\
\hline Rated power & $1,5 \mathrm{kw}$ \\
\hline
\end{tabular}

\section{REFERENCES}

[1] F. BLASHKE, The principle of fiels-orientation as applied to the Transvector closed-loop control system for rotatingfield machines ' in Siemens Reviev 34, 1972, pp. 217-220.

[2] I. TAKAHASHI, T. NOGUCHI, A new quick-response and high efficiency control strategy of an induction machine' IEEE Trans. on Industrial Application, Vol. IA22, no.5, Sept./Oct. 1986, pp. 820-827.

[3] M. DEPENBROCK, Direct Self Control of Inverter-Fed Induction Machines ' IEEE Trans. on Power Electronics, Vol. PE-3, no.4, Oct. 1988, pp. 420-429.

[4] D. Casadei, F. profum, G. Serra, and A. Tani « FOC and DTC: two viable schemes for induction motors torque control », IEEE Trans. Power Electronics, vol. 17, pp. 779786, September 2002.

[5] F. Khoucha, K. Marouani, K. Aliouane, and A. Kheloui «Experimental performance analysis of adaptive flux and speed observers for direct torque control of sensorless induction motor drives », IEEE Trans. Power Electronics Germany, pp. 2678- 2683, 2004.

[6] D. Telford, M. Dunnigan, and B.W. Williams, « A comparative of vector control and direct torque control of an induction machine », IEEE Trans. Power Electronics, pp. 421-426, 2000. 
[7] Hoang Le-Huy, « Comparison of field-oriented control and direct torque control for induction motors drives ", proceeding of IEEE Trans. Industry Appl Conf, pp. 1245$1252,1999$.

[8] T. G. Habetler, F. Profumo, M. Pastorelli, and L. M. Tolbert, "Direct torque control of induction machines using space vector modulation," IEEE Trans. Ind. Applicat., vol. 28, pp. 1045-1053, Sept./Oct. 1992.

[9] T. G. Habetler, F. Profumo, and M. Pastorelli, "Direct torque control of induction machines over a wide speed range," in Conf. Rec. IEEEIAS' 92, Houston, Oct. 1992, pp. 600-606.

[10] T. Abe, F. Profumo, G. Griva, and T. Habetler, "Evaluation of a high performance motor drive using direct torque control," in Conf. Rec. PCC'93, Yokohama, Japan, Apr. 1993, pp. 444-449.

[11] B. Robyns, B. François, P. Degobert et J. P. Hautier, « Commande Vectorielle de la Machine Asynchrone : Désensibilisation et Optimisation par la Logique floue, » Editions Technip, Paris, 2007.

\section{AUTHOR BIOGRAPHIES}

Hamid Chaikhy was born in Morocco in 1975. He received B.Sc., M. Sc. degrees at ENSET from the University of Hassan II, Mohammedia in 1998, from University of Ibno Zohr, Agadir in 2005 respectively, all in Electrical Engineering. $\mathrm{He}$ is currently working towards the Doctorate degree in Electrical Engineering at the institute of electrical and mechanical engineering (ENSEM) of the University of Hassan II, Casablanca I. His current research interests are the areas of field oriented controllers and motor drives.

Mohamed Khafallah was born in Morocco in 1964. He received B.Sc., M.Sc. and Doctorate degrees from Hassan II University, Casablanca II, in 1989, 1991 and 1995 respectively, all in Electrical Engineering. In 1995 he joined the Department of Electrical Engineering at the National School of Electricity and Mechanics (ENSEM), Hassan II University, Casablanca. His current research interests are in the application of power electronics converts and motor drives.

Abdallah Saad was born in Morocco in 1956. He received the Engineer and Doctor of Engineering degrees from National Polytechnic Institute of Grenoble - France - respectively in 1980 and 1982. From 1982 to 1986, he was Researcher at French National Center for Scientific Research (CNRS) Electrostatics and Dielectric Materials Laboratory - Grenoble. After receiving the Doctor of Physical Sciences degree in 1986, he joined Hassan II University of Morocco. Professor of electrical engineering, he has several scientific and educational responsibilities. His main fields of interest are High Voltage and Electrical Insulations, modeling and control, renewable energy integration. 